\title{
Effect of Integrated Use of Nano and Non-Nano Fertilizers on Yield and Yield Attributes of Wheat (Triticum aestivum L.)
}

\author{
Swati Mehta $^{1^{*}}$ and Rajeev Bharat ${ }^{2}$ \\ Department of Agronomy, Sher-e-Kashmir university of Agricultural Sciences and Technology \\ of Jammu, Chatha- 180 009, Jammu (Jammu and Kashmir), India \\ *Corresponding author
}

\section{A B S T R A C T}

\begin{tabular}{|l|}
\hline Ke y w o r d s \\
Nano-fertilizers, \\
Nano-K, Nano \\
NPK, Non-nano \\
fertilizers, Yield \\
and WH-1105 \\
\hline Article Info \\
\hline $\begin{array}{l}\text { Accepted: } \\
\text { 07 November } 2019 \\
\text { Available Online: } \\
\text { 10 December } 2019\end{array}$ \\
\hline
\end{tabular}

\section{Introduction}

Wheat is a cereal grain, originally from the Levant region (Feldman et al., 2007) but now cultivated worldwide. Wheat is an important source of carbohydrates (Shewry and Hey, 2015). Globally, it is the leading source of vegetal protein in human food, having a protein content of about $13 \%$, which is relatively high compared to other major cereals, but relatively low in protein quality for supplying essential amino acids. The wheat crop is grown in India in an area of about 30 million hectare with a production and productivity of 90.78 million tonnes and 2.99 tonnes per hectare respectively (Anonymous, 2016a). It is the major rabi crop of Jammu and Kashmir state and is grown on acreage of 292 
thousand hectares with an annual production of 602 thousand metric tonnes with an average productivity of 2.06 tonnes per ha (Anonymous, 2016b) which is quite low as compared to national average productivity. The green revolution of 1970's triggering high growth in agriculture which paved the way for food security in India mainly relied on short statured high yielding varieties which were responsive to inorganic fertilizers namely, Urea, DAP and MOP, thereby ensuring food security to the 1.2 billion up to early $21^{\text {st }}$ century. India is mainly dependant on inputs of fertilizers which are imported from other countries and the input costs are rising on day to day basis with subsequent reduction in subsidies on imported fertilizers by Govt. of India to save foreign exchange besides increasing the GDP of the country. Presently $35-40 \%$ of the crop productivity depends upon fertilizer, but some of the fertilizer affects the plant growth directly. Ironically, indiscriminate and imbalanced use of these inorganic fertilizers has adversely affected the soil health, human well-being besides reducing factor productivity. The application of urea, DAP and MOP have been found to have lower fertilizer efficiency which ranges from 20 to $50 \%$ for nitrogen and $10-25 \%$ for phosphorus and 70-80 \% potassium (Shaviv, 2000; Chinnamuthu and Boopathi, 2009) owing to leaching losses besides volatilization and denitrification losses which not only contribute to the green house gases emission but also certain health hazards such as blue baby syndrome as a result of eutrophication and leaching losses of urea. Because of the shortage of arable land, limited water and nutrient resources, the development of agriculture sector is only possible by increasing resource use efficiency with the minimum damage to production bed through effective use of modern technologies (Naderi and Shahraki, 2013). To overcome all these drawbacks, nanotechnology holds promise and nano-fertilizers can go a long way in ensuring sustainable soil health and crop production (Lal, 2008). The chelated \& revolutionary nutritional nano-fertilizers formulated with organic and chelated micro nutrients, trace elements, vitamins, probiotics, seaweed extract and humic acid served as complete nutritional fertilizer for all the crops. These high performance and efficient fertilizers enhanced the crop production while protecting ecology. Also, the deficiency of potassium had been reported in large area of Jammu region, therefore the nano-potassium was also included in the experiment. Thus, the present study was undertaken to evaluate the response of wheat crop to eco-friendly granular as well as foliar Nano-NPK and Nano-K fertilizers under Jammu conditions so that a viable and economically feasible option can be given to the farmers of the region for maintaining sustainable crop production with improved quality of the wheat crop. It is pertinent to mention here that no work on this aspect had been initiated in Jammu region so far.

\section{Materials and Methods}

The field experiment was conducted during rabi season of 2015-2016 at the Research Farm, FSR Centre, SKUAST-J, Main campus Chatha, Jammu. Geographically, the experimental site was located at $32^{\circ}-40^{\prime} \mathrm{N}$ latitude and $74^{\circ}-58^{\prime} \mathrm{E}$ longitude with an altitude of 332 meters above mean sea level in the Shiwalik foothills of North-Western Himalayas. The climate of the experimental site was mainly sub- tropical in nature endowed with hot and dry early summers followed by hot and humid monsoon seasons and cold and dry winters. The mean annual rainfall of the location varies from 1050 $1115 \mathrm{~mm}$ of which $70 \%$ rainfall is received from June to September, whereas the remaining $30 \%$ of rainfall is received in few scanty showers of cyclonic winter rains from December to March due to western disturbances. However, the total rainfall and 
its distribution are subjected to large variations. The soil of experimental site was clay loam in texture, slightly alkaline in reaction, low in organic carbon, available nitrogen and potassium but medium in available phosphorus. The experiment was laid out in randomized-block design with eight treatments and three replications at the research farm of Farming System Research Centre of Sher-e-Kashmir University of Agricultural Sciences and Technology of Jammu, Chatha. Urea, DAP and MOP were used as chemical sources of fertilizer and for nano-fertilizer treatments, Nano NPK and Nano-K in granular (G) and liquid forms (L) were used in the experiment.

The experiment consisted of 8 treatments viz. $\mathrm{T}_{1}$ : RDF (Control), $\mathrm{T}_{2}: 100 \% \mathrm{~N}+100 \% \mathrm{P}_{2} \mathrm{O}_{5}$ $+100 \%$ Nano-K (G) @ $62.5 \mathrm{~kg} / \mathrm{ha}, \mathrm{T}_{3}: 100 \%$ $\mathrm{N}+100 \% \mathrm{P}_{2} \mathrm{O}_{5}+50 \% \mathrm{~K}+50 \%$ Nano-K (G) @ $31.25 \mathrm{~kg} / \mathrm{ha}+2$ Nano-K (L) sprays at grain development stage at 110 and 125 DAS @ $4 \mathrm{ml} /$ litre of water, $\mathrm{T}_{4}: 75 \% \mathrm{~N}+100 \%$ $\mathrm{P}_{2} \mathrm{O}_{5}+50 \% \mathrm{~K}+50 \%$ Nano $-\mathrm{K}(\mathrm{G})$ @ 31.25 $\mathrm{kg} / \mathrm{ha}+2$ Nano-K (L) sprays at grain development stage at 110 and 125 DAS @ 4 $\mathrm{ml} /$ litre of water, $\mathrm{T}_{5}: 75 \% \mathrm{~N}+50 \% \mathrm{P}_{2} \mathrm{O}_{5}+$ $50 \%$ Nano-K $(\mathrm{G}) @ 31.25 \mathrm{~kg} / \mathrm{ha}+$ Nano NPK (G) @62.5 kg/ha, T $6: 75 \% \mathrm{~N}+50 \%$ $\mathrm{P}_{2} \mathrm{O}_{5}+100 \%$ Nano-K (G) @ $62.5 \mathrm{~kg} / \mathrm{ha}+$ Nano NPK (G) @ 37.5kg/ha + 2 Nano NPK (L) sprays at 25 and 45 DAS @ 3ml/litre of water + 2 Nano-K (L) sprays at grain development stage at 110 and 125 DAS @ 4 $\mathrm{ml} /$ litre of water, $\mathrm{T}_{7}: 100 \% \mathrm{NPK}+$ Nano NPK (L) sprays at 20,30\&45 DAS @ $3 \mathrm{ml} /$ litre of water +2 Nano-K (L) sprays at grain development stage at 110 and 125 DAS @4 $\mathrm{ml} /$ litre of water and $\mathrm{T}_{8}: 50 \% \mathrm{NPK}+$ Nano NPK (L) sprays at 20, 30 \& 45 DAS @ 3 $\mathrm{ml} /$ litre of water +2 Nano-K (L) sprays at grain development stage at 110 and 125 DAS @ $4 \mathrm{ml} /$ litre of water which was arranged in Randomized Block design with three replications. The crop variety WH-1105 was sown on $30^{\text {th }}$ November, 2015. Full dose of $P$ and $\mathrm{K}$ along with one third of $\mathrm{N}$ was applied as basal dose at the time of sowing through inorganic sources of nutrients viz. Urea, DAP and MOP, respectively and remaining two third was applied in two equal splits at CRI stage and pre booting stage. Granular as well as foliar forms of Nano-NPK and Nano-K were applied as per the treatments. Data was collected regarding yield and yield attributes of wheat grains. Data recorded on various parameters of the experiment was subjected to analysis by using Fisher's method of analysis of variance (ANOVA) and interpreted as outlined by Gomez and Gomez (1984). The level of significance used in ' $F$ ' and ' $t$ ' test was $p=0.05$. Critical difference values were calculated where $\mathrm{F}$ test was found significant.

\section{Results and Discussion}

\section{Yield attributes}

The data on various yield attributes viz. effective tillers per metre row length, length of ear $(\mathrm{cm})$, number of grains per ear and 1000grain weight (g) as influenced by the integrated use of nano and non-nano fertilizers were recorded and presented in Table 1. Data indicated that among the applied treatments, $\mathrm{T}_{7}(100 \% \mathrm{NPK}+$ Nano NPK (L) sprays at 20, 30 \& 45 DAS @ 3 ml/litre of water + 2 Nano$\mathrm{K}$ (L) sprays at grain development stage at 110 and 125 DAS @ $4 \mathrm{ml} /$ litre of water) though at par with the treatment $\mathrm{T}_{3}(100 \% \mathrm{~N}+100 \%$ $\mathrm{P}_{2} \mathrm{O}_{5}+50 \% \mathrm{~K}+50 \%$ Nano-K $(\mathrm{G}) @ 31.25$ $\mathrm{kg} / \mathrm{ha}+2$ Nano-K (L) sprays at grain development stage at 110 and 125 DAS @ 4 $\mathrm{ml} /$ litre of water), $\mathrm{T}_{2}\left(100 \% \mathrm{~N}+100 \% \mathrm{P}_{2} \mathrm{O}_{5}\right.$ $+100 \%$ Nano-K $(\mathrm{G}) @ 62.5 \mathrm{~kg} / \mathrm{ha})$ and $\mathrm{T}_{1}$ (RDF) recorded significantly higher number of effective tillers (75.19), maximum length of the ear $(14.38 \mathrm{~cm})$, maximum number of grains per ear (39.06) and highest 1000-grain weight $(42.50 \mathrm{~g})$, than the control and other treatments in comparison. The increase in 
yield attributes viz. number of effective tillers/metre row length, length of ear $(\mathrm{cm})$, number of grains per ear, 1000-grain weight may be due to the reason that nano-NPK promotes the plant to absorb the water of soil and nutrients, then the photosynthesis is improved (Wu, 2013). Further, nano-NPK is considered the biological pump for the plants to absorb nutrients and water (Ma et al., 2009). Liu and Liao (2008) reported increased water uptake due to application of nanomaterials which increased the $\mathrm{N}, \mathrm{P} \& \mathrm{~K}$ uptake and resulted in increased biomass production. However, treatment $\mathrm{T}_{8}(50 \%$ NPK + Nano NPK (L) sprays at $20,30 \& 45$ DAS @ $3 \mathrm{ml} /$ litre of water + 2 Nano-K (L) sprays at grain development stage at 110 and 125 DAS @ $4 \mathrm{ml} /$ litre of water) recorded significantly lowest number of effective tillers (63.17), minimum length of the ear $(9.54 \mathrm{~cm})$, minimum number of grains per ear (31.72) and lowest 1000-grain weight (35.79 g).

\section{Grain and straw yield}

The integrated use of nano and non-nano fertilizers had significant effect on the grain yield. The data presented in Table 2 and Figure 1 depicts that treatment $\mathrm{T}_{7}(100 \%$ NPK + Nano NPK (L) sprays at 20, 30 \& 45 DAS @ $3 \mathrm{ml} /$ litre of water +2 Nano-K (L) sprays at grain development stage at 110 and 125 DAS @ $4 \mathrm{ml} /$ litre of water) recorded significantly maximum grain yield $(44.45 \mathrm{q} / \mathrm{ha})$ and straw yield $(55.99 \mathrm{q} / \mathrm{ha})$ which was however, statistically at par with the treatment $\mathrm{T}_{3}(100$ $\% \mathrm{~N}+100 \% \mathrm{P}_{2} \mathrm{O}_{5}+50 \% \mathrm{~K}+50 \%$ Nano-K (G) @ $31.25 \mathrm{~kg} / \mathrm{ha}+2$ Nano-K (L) sprays at grain development stage at 110 and 125 DAS @ $4 \mathrm{ml} /$ litre of water) and $\mathrm{T}_{2}(100 \% \mathrm{~N}+100$ $\% \mathrm{P}_{2} \mathrm{O}_{5}+100 \%$ Nano-K (G) @ $\left.62.5 \mathrm{~kg} / \mathrm{ha}\right)$. Benzon et al., (2015) reported synergistic effect of the nano-fertilizers on the efficacy of conventional fertilizer for better nutrient absorption by plant cells resulting to optimal growth plant parts and metabolic process such as photosynthesis leads to higher photosynthates accumulation and translocation to the economic parts of the plant, thus resulting in high yield which may be attributed to increased source (leaves) and sink (economic part) strength (Taiz and Zeiger, 2006). Foliar application of Nano-fertilizers significantly increase the crop yield (Tarafdar et al., 2012). As mentioned earlier, nanofertilizers may have affected these processes through its nutrient transportation capability in terms of penetration and movement of a wide range of nutrients, from roots uptake to foliage penetration and movements within the plant.

A number of studies proved the significance of nano-fertilizers. For instance, Sirisena et al., (2013) obtained higher grain yield in rice with the application of nano-K fertilizer. This is in agreement with the findings of Liu et al., (2009), Harsini et al., (2014), Azizet al., (2016), Hafeez et al., (2015), Jafarzadeh et al., (2013), Kumar et al., (2014), Sheikhbaglou et al., (2010) and Sirisena et al., (2013).The significantly minimum grain yield (28.23 $\mathrm{q} / \mathrm{ha})$ and straw yield $(38.92 \mathrm{q} / \mathrm{ha})$ was recorded in treatment $\mathrm{T}_{8}(50 \% \mathrm{NPK}+\mathrm{Nano}$ NPK (L) sprays at $20,30 \& 45$ DAS @ 3 $\mathrm{ml} /$ litre of water +2 Nano-K (L) sprays at grain development stage at 110 and 125 DAS @ $4 \mathrm{ml} /$ litre of water).

\section{Harvest index (\%)}

The data pertinent to the harvest index in Table 2 reveals that the effect of integrated use of nano and non-nano fertilizers on the harvest index was found to be non-significant. 
Table.1 Effect of integrated use of nano and non-nano fertilizers on yield attributes of wheat

\begin{tabular}{|c|c|c|c|c|c|}
\hline \multicolumn{2}{|c|}{$\begin{array}{rr}\text { Treatments } \\
\end{array}$} & \multirow{2}{*}{\begin{tabular}{|c|}
$\begin{array}{l}\text { Effective } \\
\text { tillers/m }\end{array}$ \\
72.03 \\
\end{tabular}} & \multirow{2}{*}{$\begin{array}{c}\begin{array}{c}\text { Length } \\
\text { of the } \\
\text { ear } \\
\text { (cm) }\end{array} \\
11.61\end{array}$} & \multirow{2}{*}{$\begin{array}{l}\text { Grains } \\
\text { per } \\
\text { ear }\end{array}$} & \multirow{2}{*}{$\begin{array}{c}\begin{array}{c}\text { 1000- } \\
\text { grain } \\
\text { weight } \\
\text { (g) }\end{array} \\
39.53\end{array}$} \\
\hline $\mathbf{T}_{1}$ & RDF (control) (N:P:K @ 100:50:25 kg/ha) & & & & \\
\hline $\mathbf{T}_{2}$ & $\begin{array}{c}100 \% \mathrm{~N}+100 \% \mathrm{P}_{2} \mathrm{O}_{5}+100 \% \text { Nano-K }(\mathrm{G}) \\
@ 62.5 \mathrm{~kg} / \mathrm{ha}\end{array}$ & 73.78 & 12.10 & 36.72 & 40.91 \\
\hline $\mathbf{T}_{3}$ & $\begin{array}{c}100 \% \mathrm{~N}+100 \% \mathrm{P}_{2} \mathrm{O}_{5}+50 \% \mathrm{~K}+50 \% \text { Nano-K } \\
\text { (G) @ } 31.25 \mathrm{~kg} / \mathrm{ha}+2 \mathrm{Nano}-\mathrm{K}(\mathrm{L}) \text { sprays at grain } \\
\text { development stage at } 110 \text { and } 125 \text { DAS @ } 4 \\
\text { ml/litre of water }\end{array}$ & 74.25 & 13.36 & 37.72 & 41.31 \\
\hline $\mathbf{T}_{4}$ & $\begin{array}{c}75 \% \mathrm{~N}+100 \% \mathrm{P}_{2} \mathrm{O}_{5}+50 \% \mathrm{~K}+50 \% \text { Nano-K } \\
\text { (G) @ } 31.25 \mathrm{~kg} / \mathrm{ha}+2 \mathrm{Nano}-\mathrm{K} \text { (L) sprays at grain } \\
\text { development stage at } 110 \text { and } 125 \text { DAS @ } 4 \\
\mathrm{ml} / \text { litre of water }\end{array}$ & 71.91 & 11.47 & 35.81 & 38.28 \\
\hline $\mathbf{T}_{5}$ & $\begin{array}{c}75 \% \mathrm{~N}+50 \% \mathrm{P}_{2} \mathrm{O}_{5}+50 \% \text { Nano-K }(\mathrm{G}) @ 31.25 \\
\mathrm{~kg} / \mathrm{ha}+\text { Nano NPK }(\mathrm{G}) @ 62.5 \mathrm{~kg} / \mathrm{ha}\end{array}$ & 69.78 & 10.41 & 32.61 & 36.47 \\
\hline $\mathbf{T}_{6}$ & $\begin{array}{l}75 \% \mathrm{~N}+50 \% \mathrm{P}_{2} \mathrm{O}_{5}+100 \% \text { Nano-K (G) @62.5 } \\
\mathrm{kg} / \mathrm{ha}+\mathrm{Nano} \mathrm{NPK}(\mathrm{G}) @ 37.5 \mathrm{~kg} / \mathrm{ha}+2 \mathrm{Nano} \\
\mathrm{NPK}(\mathrm{L}) \text { sprays at } 25 \text { and } 45 \mathrm{DAS} @ 3 \mathrm{ml} / \mathrm{litre} \text { of } \\
\text { water }+2 \text { Nano-K }(\mathrm{L}) \text { sprays at grain development } \\
\text { stage at } 110 \text { and } 125 \mathrm{DAS} @ 4 \mathrm{ml} / \mathrm{litre} \text { of water }\end{array}$ & 71.97 & 11.34 & 34.50 & 38.66 \\
\hline $\mathbf{T}_{7}$ & $\begin{array}{c}\text { RDF + } 3 \text { Nano NPK (L) sprays at } 20,35 \text { and } 45 \\
\text { DAS @ } 3 \text { ml/litre of water + } 2 \text { Nano-K (L) sprays } \\
\text { at grain development stage at } 110 \text { and } 125 \text { DAS @ } \\
4 \text { ml/litre of water }\end{array}$ & 75.19 & 14.38 & 39.06 & 42.50 \\
\hline $\mathbf{T}_{8}$ & $\begin{array}{c}50 \% \text { RDF + } 3 \text { Nano NPK (L) sprays at } 20,35 \text { and } \\
45 \text { DAS @ } 3 \mathrm{ml} / \text { litre of water + } 2 \text { Nano-K (L) } \\
\text { sprays at grain development stage at } 110 \text { and } 125 \\
\text { DAS @ } 4 \text { ml/litre of water }\end{array}$ & 63.17 & 9.54 & 31.72 & 35.79 \\
\hline & SEm \pm & 1.70 & 0.42 & 1.04 & 1.16 \\
\hline & CD (5\%) & 5.17 & 1.30 & 3.15 & 3.53 \\
\hline
\end{tabular}

*Granular - (G)

*Liquid $\quad-(\mathbf{L})$ 
Table.2 Effect of integrated use of nano and non-nano fertilizers on grain yield, straw yield, biological yield and harvest index of wheat

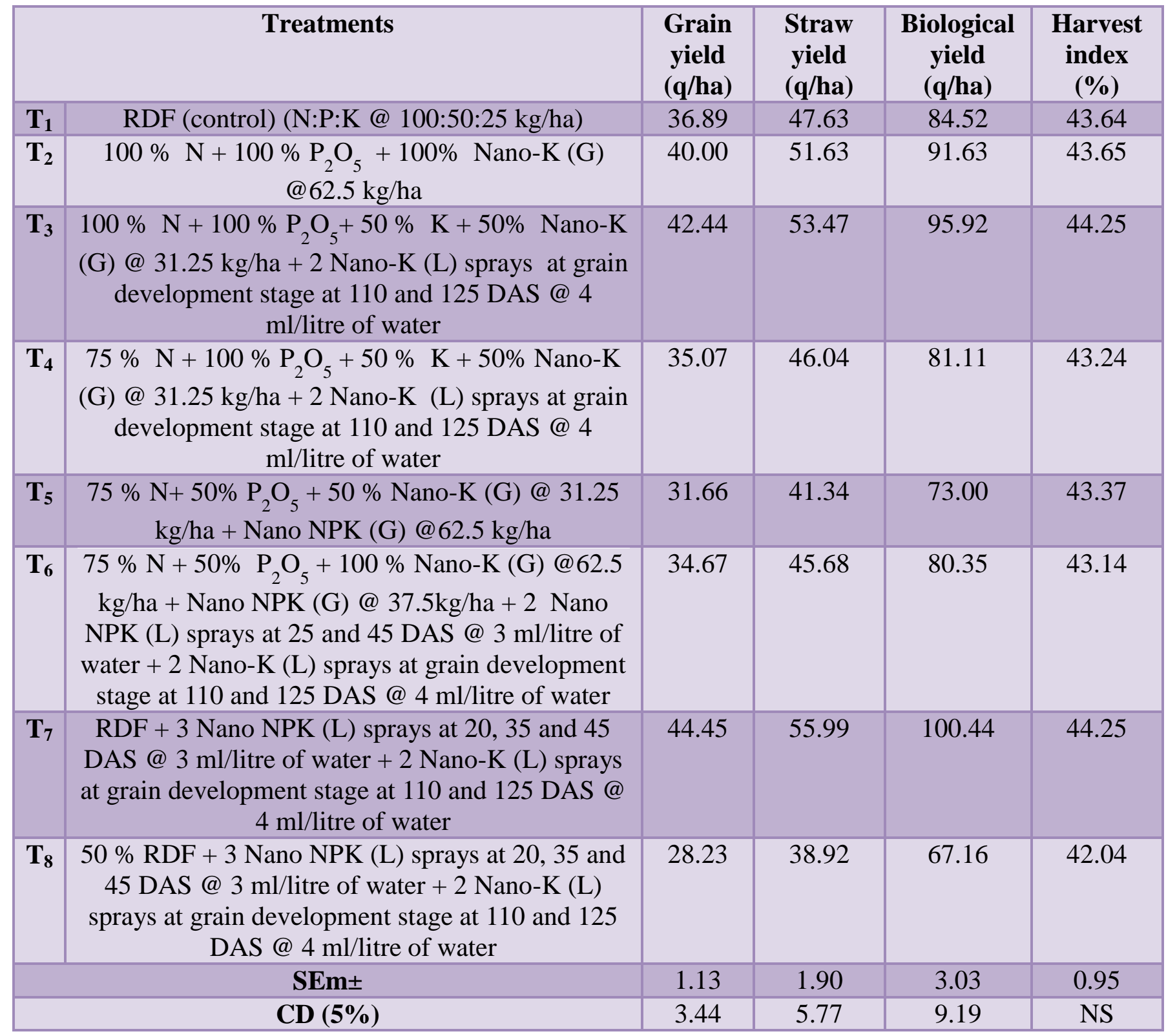

*Granular - (G)

*Liquid $\quad-(\mathbf{L})$ 
Fig.1 Effect of integrated use of nano and non-nano fertilizers on grain yield and straw yield of wheat

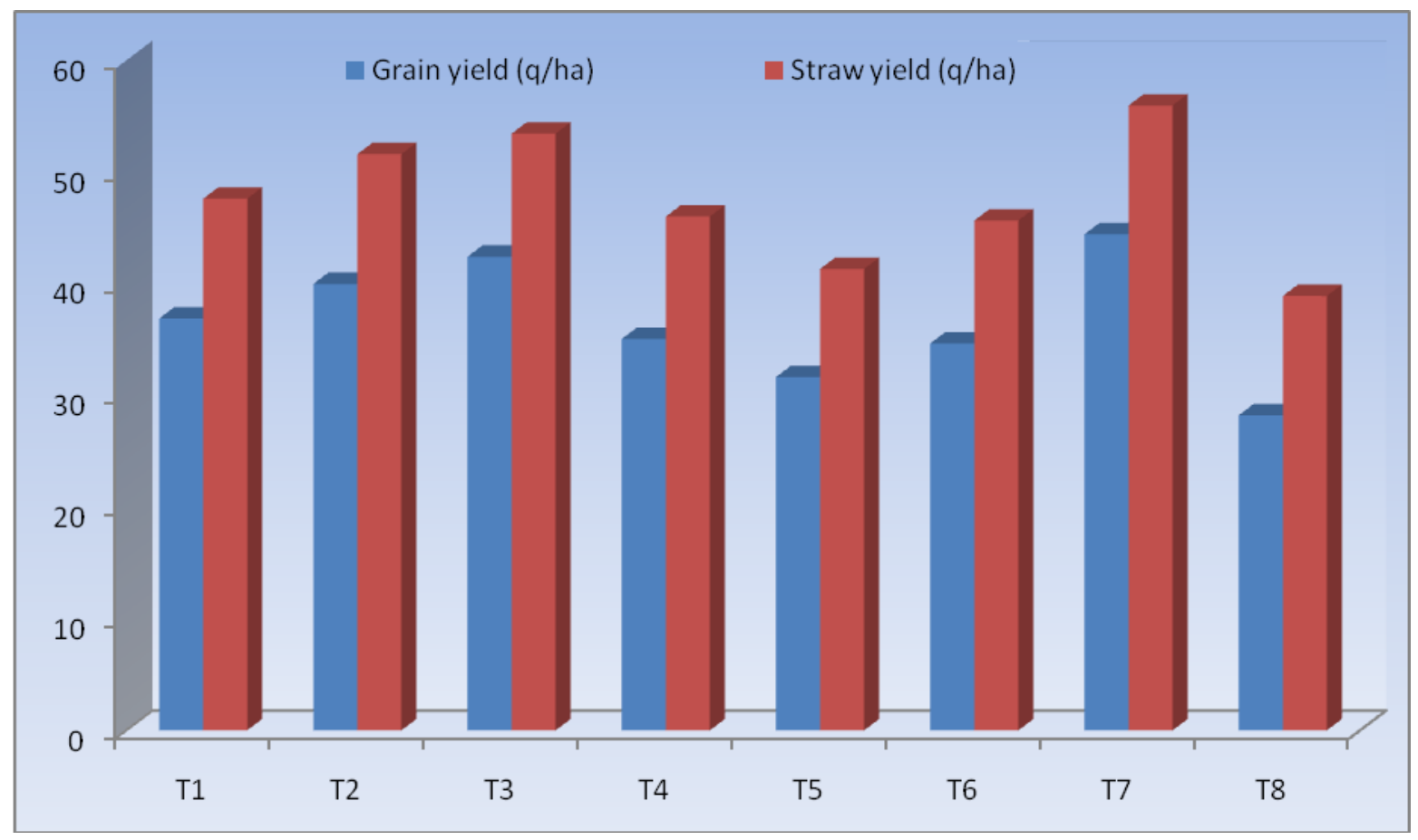

Treatment $\mathrm{T}_{7}(100 \%$ NPK + Nano NPK (L) sprays at 20,30 and 45 DAS @ $3 \mathrm{ml} /$ litre of water +2 Nano-K (L) sprays at grain development stage at 110 and 125 DAS @ 4 $\mathrm{ml} /$ litre of water) recorded the maximum harvest index $(44.25 \%)$ whereas the minimum harvest index i.e. $42.04 \%$ was recorded in treatment $\mathrm{T}_{8}(50 \% \mathrm{NPK}+$ Nano NPK (L) sprays at 20,30 and 45 DAS @ $3 \mathrm{ml} /$ litre of water +2 Nano-K (L) sprays at grain development stage at110 and 125 DAS @ $4 \mathrm{ml} /$ litre of water.

On the basis of one year study, it is concluded that among the different integrated nano and non-nano fertilizers, treatment $\mathrm{T}_{7}(100 \% \mathrm{NPK}$ + Nano NPK (L) sprays at 20, 30 \& 45 DAS @ $3 \mathrm{ml} /$ litre of water +2 Nano-K (L) sprays at grain development stage at 110 and 125 DAS @ $4 \mathrm{ml} /$ litre of water) was found to be the best treatment in increasing the crop yield and yield attributes of wheat crop.

\section{References}

Anonymous. 2016a. Agricultural Statistics at a glance. Directorate of Economics \& Statistics, Ministry of Agriculture Department of Agriculture \& cooperation. Government of India.

Anonymous. 2016b. Economic survey. Directorate of Economics \& Statistics, Government of Jammu \& Kashmir.

Aziz, H. M. M., Hasaneen, M. N. A. and Omer, A. M. 2016. Nano chitosanNPK fertilizer enhances the growth and productivity of wheat plants grown in sandy soil. Spanish Journal of Agricultural Research, 14(1): e0902.

Benzon, H., Rubenecia, M., Ultra, V. and Lee, S. 2015. Nano-fertilizer affects the growth, development, and chemical properties of rice. International Journal of Agronomy and Agricultural Research (IJAAR), 7(1): 105-117. 
Chinnamuthu, C. R. and Boopathi, P. M. 2009. Nano-technology and Agroecosystem. Madras Agricultural Journal, 96: 17-31.

Feldman, Moshe, Kislev and Mordechai, E. 2007. Domestication of emmer wheat and evolution of free-threshing tetraploid wheat in "A Century of Wheat Research- from Wild Emmer Discovery to Genome Analysis. Israel Journal of Plant Sciences, 55(3): 207221.

Gomez A K and Gomez AA. 1984. Statistical Procedures for Agriculture Res. Awiley - Inter Science Publication. John Wiley and Sons, New York. pp. 680.

Hafeez, A., Razzaq, A., Mahmood, T. and Jhanzab, H. M. 2015.Potential of copper nano-particles to increase growth and yield of wheat. Journal of Nano science with Advanced Technology, 1(1): 6-11.

Harsini, M. G., Habibi, H. and Talaei, G. H. 2014. Study the effects of iron nano chelated fertilizers foliar application on yield and yield components of new line of wheat cold region of Kermanshah province. Agriculture Advances, 3(4): 95-102.

Jafarzadeh, R., Jami, M. and Hokmabadi, M. 2013.Response of yield and yield components in wheat to soil and foliar application of Nano Potassium fertilizer.Journal of crop production research (Environmental stresses in Plant Sciences ), 5(2): 189-197.

Kumar, R., Pandey, D. S., Singh, V. P. and Singh, I. P. 2014. Nano-technology for better fertilizer use (Research Experiences at Pantnagar). Research Bulletin no. 201.

Lal, R. 2008. Promise and limitations of soils to minimize climate change. Journal of Soil Water Conservation, 63: 113A118A.
Liu, A. X. and Liao, Z. W. 2008. Effects of nano-materials on water clusters. Journal of Anhui Agricultural Sciences, 36: 15780-15781.

Liu J., Zhang Y. and Zhang Z. 2009.The application research on nanobiotechnology to promote increasing vegetable production. Hubei Agricultural Sciences, 1: 20-25.

Ma, Y., Kuang, L., He, X., Bai, W., Ding, Y., Zhang, Z., Zhao, Y. and Chai, Z. 2009. Effect of rare earth oxide nanoparticles on root elongation of plants.Chemosphere, 78: 273-279.

Naderi, M. and Shahraki, A. 2013.Nanofertilizers and their roles in sustainable agriculture. International Journal of Agriculture and Crop Science, 5(19): 2229-2232.

Nichiporovich, A. A. 1967. Aims of research on the Photosynthesis of plants as a factor of productivity. In: Nichiporovich A. A. Photosynthesis of productive system. Israel Programme Science Trans Jerusalem, pp: 3-36.

Shaviv, A. 2000.Advances in controlled release of fertilizers. Advanced Agronomy Journal, 71: 1-49.

Shewry, P. R. and Hey, S. J. 2015. Review: The contribution of wheat to human diet and health. Food and Energy Security, 4(3): 178-202.

Sheikhbaglou, R., Sedghi, M., Tajbakhsh, S. M. and Seyed-Sharifi, R. 2010.Effect of nano iron particles on agronomic traits of soybean. Science Biological, 2(2): 112-113.

Sirisena, D. N, Dissanayake D. M. N., Somaweera K. A. T. N., Karunaratne V. and Kottegoda, N. 2013. Use of Nano-K fertilizer as a source of potassium in rice cultivation. Annals of Sri Lanka Department of Agriculture, 15: 257-262.

Taiz, L. and Zeiger, E. 2006. Plant physiology, $4^{\text {th }}$ Edition. Sinauer 
Associates, Inc. Sunderland, Wu, M. 2013. Effects of incorporation of Massaschusetts, USA. nano-carbon into slow-released Tarafdar, J. C., Sharma, S. and Raliya, R. fertilizer on rice yield and nitrogen loss 2012. Nano-technology: Interdisciplinary science of applications. African Journal of Biotechnology, 12(3): 219- 226. in surface water of paddy soil. Advance Journal of Food Science and Technology, 5: 398-403.

\section{How to cite this article:}

Swati Mehta and Rajeev Bharat. 2019. Effect of Integrated Use of Nano and Non-Nano Fertilizers on Yield and Yield Attributes of Wheat (Triticum aestivum L.). Int.J.Curr.Microbiol.App.Sci. 8(12): 598-606. doi: https://doi.org/10.20546/ijcmas.2019.812.078 